\title{
Discipline: Still A Four Letter Word?
}

Jane Whitney Gibson, (E-mail: Gibson@huizenga.nova.edu), Nova Southeastern University

Susan P. Cotterman, Baker College

Robert E. Johnson, Baker College

\begin{abstract}
Discipline is an unpleasant part of the manager's job and often handled poorly. This article examines the reason for this phenomenon and focuses on the need for due process. The traditional and nonpunitive discipline systems are compared and contrasted. Guidelines are presented for setting up workable discipline systems and for becoming more proficient at handing discipline situations.
\end{abstract}

\section{INTRODUCTION}

s discipline a dirty word in your organization? Knowing how and when to discipline employees is an
essential part of the supervisor's job, but unfortunately it is often handled poorly. When rule violations
occur, many supervisors look the other way. There are at least three reasons why supervisors often neglect their responsibility to administer discipline. First, discipline seems to imply an unpleasant confrontation with the employee. Discipline discussions often lead to resentment by the employee in question and thus further problems. Second, supervisors often observe that the "rules" are broken randomly around the company and that other infractions have gone unnoticed or at least unpunished. Third, many supervisors are unsure how to conduct the discipline interview, how to document those discussions, and what to do next. They simply haven't been trained adequately. (Gibson, 1995) This article provides a filter through which you can reexamine your organization's discipline process and your own skills in handling discipline situations. We begin by reviewing the need for due process; then we look at traditional vs. nonpunitive discipline systems. Finally, we offer some guidelines which may make you more effective in administering discipline where you work.

\section{THE NEED FOR DUE PROCESS}

All employees should be accorded due process. Any termination of an employee that has not been given an opportunity to change or correct their behavior in the workplace could be grounds for legal action by the terminated employee. (Dhanoa \& Kleiner, 2000) In order for an organization to avoid legal action, there must be guidelines in place that are well communicated to employees about what constitutes appropriate and inappropriate behavior. There should also be policies and procedures describing what will happen when infractions occur. These policies and procedures along with documentation that the latter were followed can be very helpful in avoiding or winning wrongful discharge cases. Perhaps more importantly, due process makes employees feel that they are working in a fair environment where everyone is treated the same way. Consistency is the key. The perception of fairness has become ever more important in our increasingly diverse workplaces.

Even after the best efforts have been made to build a positive climate for adherence to rules and standards of performance and behavior, violations will occur and the supervisor must be adequately prepared to administer constructive discipline in a tactful and effective manner. When disciplining employees, keep in mind four key words: consistency, warning, clarity, and immediacy. Consistency has already been mentioned. Warning refers to informing the employee of a problem as soon as it is noticed and before it becomes a major issue. Often supervisors fail to let employees know there is any problem until the problem becomes so big that they can endure it no longer. The employee may be blindsided when the supervisor explodes over some previously unmentioned infraction. 
Clarity emphasizes the need to make perfectly clear to employees exactly what they have done wrong or what is or is not appropriate behavior. Immediacy refers to the need to discipline quickly although the supervisor should never do so in public and should always confine remarks to the issue at hand. Don't use the situation to rehash everything the employee has ever done wrong or to remind him or her of how much you have let slide in the past.

The exact process the supervisor will follow depends to a great extent on whether the organization has chosen to follow the traditional or nonpunitive model.

\section{THE TRADITIONAL DISCIPLINE SYSTEM}

Traditional progressive discipline was first developed in the 1930s. This was in response to the call for a "just cause" method to terminating employees required under the National Labor Relations Act of 1935. Its four steps as shown in Figure 1 are designed to address identical offenses in identical ways. (Guffey \& Helms, 2001)

Figure 1 Traditional vs Nonpunitive Discipline

\begin{tabular}{|c|l|l|}
\hline Stage & \multicolumn{1}{|c|}{ Traditional } & \multicolumn{1}{c|}{ Nonpunitive } \\
\hline 1 & Oral warning & Informal counseling session \\
\hline 2 & Written warning with focus on the past & Formal counseling session, written reminder, focus on the future \\
\hline 3 & Unpaid suspension & Paid "decision day" \\
\hline 4 & Involuntary termination & Voluntary or involuntary termination \\
\hline
\end{tabular}

The first step in the traditional discipline process is an oral warning where the employee is informed of the discrepancy between his or her performance and the expected performance. Although no written record of this warning goes into the employee's file, supervisors are encouraged to take notes during this meeting. Employees are usually given a timeframe in which to improve the performance or behavior and told what the next step will be if improvement doesn't materialize.

The second step is a written warning which is reviewed with the employee and placed in the employee's file. Again, a timeframe is generally given at this point along with a formal improvement plan. The employee is informed of the consequences of failing to meet this improvement plan. If the goals are not met, the third step of the traditional process is an unpaid suspension which is typically one day but can be longer. The employee is informed, if there is no improvement upon returning to work, that termination will be next. Lack of action at this point on the part of management can have an infectious result and hurt the performance of other employees. If it is decided to terminate an employee, then the action should be quick. (Christie \& Kleiner, 2000)

The process of traditional discipline is punitive and retributive. The focus is on the employee's past performance problems. The process is vertical with the supervisor handing down warnings and reprimands similar to the way a parent scolds a child. This may cause resentment and a poor relationship between the supervisor and employee. It is a system with which many supervisors are uncomfortable, leading them to ignore some problem behaviors rather than addressing them in this confrontational manner. For these reasons, many supervisors are more comfortable with the nonpunitive discipline system.

\section{THE NONPUNITIVE DISCIPLINE SYSTEM}

Nonpunitive discipline is another form of progressive discipline. The goal of nonpunitive discipline is to empower the employee to be responsible for improving problematic work behaviors. It relies on corrective counseling rather than traditional discipline sessions. As shown in Figure 1, the first stage of nonpunitive discipline is an informal counseling session. This is similar to the traditional oral warning except the focus is on aiding the employee to change the behavior through positive counseling as opposed to warnings. No threats of future corrective action are mentioned at this time and no written record is kept. The meeting ends with an agreement on a viable solution to the problem behavior. 
Step two of the nonpunitive system begins when the employee's behavior has not changed in the agreed upon time frame. Step two is a written reminder and a formal counseling session. As with the traditional method, a record is placed in the employee's file. However, the focus is on the employee's future performance goals and the methods needed to achieve them instead of the employee's past performance.

The next step in the nonpunitive system shows the largest difference in the two systems. It is a paid, "decision-making" day off from work. With the traditional system, the unpaid suspension day(s) do little to correct the employee's behavior and instead can create increased resentment and tension. With the paid decision day, the employer empowers the employee to make the decision regarding his or her commitment to the organization and the desire to change the problem behavior. If the employee decides he cannot make the necessary commitment to change, then his option is to voluntarily quit. (Riccucci \& Wheeler, 1987)

\section{COMPARING THE TWO MODELS}

When used properly, the traditional model may alter the individual employee's behavior and it may deter similar behavior among other employees. Surely it is designed to maintain standards in the workplace. However, as we have already indicated, traditional discipline procedures run the risk of further alienating potentially good employees by making them resentful, even hostile. The traditional model perpetuates the old "I am the boss," model of supervision and creates a predominantly vertical problem-solving environment. It is the system typically built into most collective bargaining agreements.

In contrast, the nonpunitive system operates in a horizontal environment where the supervisor assumes the role of coach and the employee in questions shoulders primary responsibility for solving whatever performance or behavioral problem that exists. It often includes features like alternative dispute resolution, expunging of disciplinary records from workers' files, arriving at last chance agreements, allowing paid reflective time off and even working suspensions. Employee-proposed discipline is another feature which has been tried in conjunction with nonpunitive discipline. In these organizations, employees are invited to suggest their own discipline when infractions occur. While often proposing fairly lenient sanctions for themselves, employee-proposed discipline again puts the responsibility for complying with organizational rules and regulations on the shoulders of the offending employee. (King \& Wilcox, 2003) Regardless of which system the supervisor uses, the key is to be prepared.

\section{BEFORE, DURING, AND AFTER DISCIPLINE}

Here are some tips as to how you can become more proficient during the discipline process:

1. Reexamine the discipline policies within your own organization. Be sure you are very familiar with the guidelines. Does the system seem more traditional or nonpunitive? The answer to this will somewhat guide how you behave during the various steps of the discipline procedure.

2. Be sure that you are doing all you can to educate your employees as to the expectations of the job. Don't expect them to know that lunch hours are strictly regulated or that teamwork is a valued skill. Likewise don't assume they're read the procedure manual and know that personal time cannot be combined with vacation time or that they cannot use the company's computer server for surfing gambling sites even though they are on their lunch break. Admonishing someone for "breaking the rules" only makes sense if they knew about the rules to begin with.

3. Be sure that you are consistent and fair with all employees when it comes to discipline. You cannot let the most productive employee in the company come in late every day if you are going to criticize the newcomer for the same behavior.

4. When engaging in a discipline-related discussion, be courteous and never admonish anyone in public or when you are angry. Be careful to confine your remarks to the issue at hand. Be sure that you are clear about the behaviors that need to be changed or stopped. Simply telling an employee he or she has to do a better job at getting along with people is too vague. Be specific.

5. Regardless of which system of discipline you are using, be careful to document everything. The single biggest mistake that supervisors make in the disciplinary process is not documenting the facts as they 
occur. Grievances often result when supervisors try to discharge or seriously discipline an employee for repeated offenses when, in fact, they have no evidence that these previous offenses were ever discussed.

\section{CONCLUSION}

While it is doubtful that discipline will ever be one of your favorite job responsibilities, you can make it considerably less daunting by examining your current readiness level and developing your skills where needed. Don't be afraid to ask the human resources department for help; they are likely to have documented discipline procedures and may even provide some additional training. The need for discipline is not likely to disappear, but with concerted effort, we can make it less of a four letter word!

\section{REFERENCES}

1. Christie, B. \& Kleiner, H. B. (2000). How to conduct due process discipline. Management Research News, 19:6-7, 40-44.

2. Dhanoa, S. D. \& Kleiner, H. B. (2000). How to conduct due process discipline. Management Research News, 23(7/8): 89-94.

3. Gibson, J. W. (1995). The Supervisory Challenge: Principles and Practices. (2 $2^{\text {nd }}$ ed). Englewood Cliffs, N. J., Prentice Hall.

4. Guffey, C. J. \& Helms, M. M. (Spring, 2001). Effective employee discipline: A case of the Internal Revenue Service. (Electronic version) Public Personnel Management, 30, 111-127.

5. King, K. N. \& Wilcox, D. E. (Summer 2003). Employee-proposed discipline: How well is it working? Public Personnel Management, 32: 2, 197.

6. Riccucci, N. M. \& Wheeler, G. R. (Fall 1987). Positive employee performance: An innovative approach to employee discipline (Electronic version) Review of Public Personnel Administration, 8, 49-63. 